Article available at nttp://WwW.parasite-journal.org or nttp://dx.dol.org/10.1051/parasite/2004112119

\title{
NemATOdE PARASITES OF ANIMALS ARE MORE PRONE TO DEVELOP XENOBIOTIC RESISTANCE THAN NEMATODE PARASITES OF PLANTS
}

\author{
SILVESTRE A*. \& CABARET J*.
}

\section{Summary:}

In this paper, we concentrate on a comparison of plant and animal-parasitic nematodes, to gain insight into the factors that influence the acquisition of the drug resistance by nematodes. Comparing nematode parasite of domestic animals and cultivated plants, it appears that drug resistance threatens only domestic animal production. Does the paucity of report on nematicide field resistance reflect reality or, is nematicide resistance bypassed by other management practices, specific to cultivated plants (i.e. agricultural control)? First, it seems that selection pressure by treatments in plants is not as efficient as selection pressure in ruminants. Agronomic practices (i.e. sanitation, early planting, usage of nematodes resistant cultivar and crop rotation) are frequently used to control parasitic-plant nematodes. Although the efficiency of such measures is generally moderate to high, integrated approaches are developing successfully in parasiticplant nematode models. Secondly, the majority of anthelmintic resistance cases recorded in animal-parasitic nematodes concern drug families that are not used in plant-parasitic nematodes control (i.e. benzimidazoles, avermectines and levamisole). Thirdly, particular life traits of parasitic-plant nematodes (low to moderate fecundity and reproductive strategy) are expected to reduce probability of appearance and transmission of drug resistance genes. It has been demonstrated that, for a large number of nematodes such as Meloidogyne spp., the mode of reproduction by mitotic parthenogenesis reduced genetic diversity of populations which may prevent a rapid drug resistance development. In conclusion, anthelmintic resistance develops in nematode parasite of animals as a consequence of an efficient selection pressure. Early detection of anthelmintic resistance is then crucial: it is not possible to avoid it, but only to delay its development in farm animal industry.

KEY WORDS : drug resistance, parasitic nematodes, nematicide, anthelmintics. MOTS CLÉS : résistance, nématode parasite, nématicide, anthelminthique

\section{INTRODUCTION}

N ematodes are very important parasites: plantparasitic nematode infections result in losses of more than $\$ 100$ billion per year (Opperman \&

\footnotetext{
* INRA, BioAgresseurs, Santé et Environnement, 37380 Nouzilly, France.

Correspondence: Anne Silvestre.

Tel.: 33 (0) 247427683 - Fax: 33 (0) 247427774 .

E-mail: silvestr@tours.inra.fr
}

Résumé : Les NÉMATOdes PARASITES D'ANIMAUX SONT PLUS ENCLINS À DÉVELOPPER UNE RÉSISTANCE AUX TRAITEMENTS QUE LES NÉMATODES PHYTOPARASITES

Un comparatif entre les nématodes phytoparasites et les nématodes parasites d'animaux de rente est réalisé afin de connaître les facteurs influençant l'acquisition de la résistance aux traitements. La résistance anthelminthique ne pose de problème que chez les animaux d'élevage. Est-ce que l'absence de résistance au champ est due au peu de cas connus de résistance aux nématicides, ou bien, est-ce que la résistance aux nématicides est contournée par les pratiques culturales, telles que l'assolement, par exemple? D'une part, il semble que la pression de sélection par les traitements chez les plantes n'est pas aussi forte que la pression de sélection exercée chez les animaux de rente. En agronomie, le labour, le semis précoce, l'utilisation de variétés résistantes aux nématodes et la rotation culturale sont souvent utilisés pour contrôler les infestations. Bien que modérément efficaces individuellement, ces mesures utilisées dans le cadre de la lutte intégrée réduisent efficacement les populations de nématodes. D'autre part, la résistance aux anthelminthiques, chez les nématodes parasites d'animaux, est essentiellement dirigée contre des familles de molécules qui ne sont pas utilisées dans le contrôle des nématodes phytoparasites (benzimidazoles, avermectines et lévamisole). Enfin, certains traits d'histoire de vie des nématodes phytoparasites (fécondité et mode de reproduction) sont susceptibles de réduire la probabilité d'apparition et de transmission des gènes de résistance. Il a été démontré que pour un grand nombre de nématodes, tel que Meloidogyne spp., le mode de reproduction par parthénogenèse mitotique réduisait la diversité génétique des populations, ce qui peut ralentir le développement de la résistance aux traitements. En conclusion, c'est la forte pression de sélection exercée par les traitements qui est responsable du développement de la résistance anthelminthique chez les nématodes parasites d'animaux. Puisque le développement de la résistance anthelminthique est inévitable, il est déterminant de pouvoir la détecter précocement de manière à ralentir son développement chez les nématodes parasites d'animaux de rente. 
dies (identification of target gene) but differences between life history and habitat in comparison with parasitic nematodes may limit its usefulness for studying ecological factors (i.e. migration (Roush \& McKenzie, 1987)) or functional factors (i.e. fitness and population in refuge (Raymond et al., 1991)) implicated in drug resistance acquisition.

Many factors may influence the rate at which drug resistance spreads in a population, and the effect of a given factor may vary widely in different contexts (Silvestre et al., 2001). Wood \& Mani (1981) classified factors into four groups:

- genetic factors: mutation rate, dominance of the trait; - reproductive factors: number of generations per year, fluctuations in population size;

- ecological factors: migration of parasite and ability to avoid the drug;

- operational factors: proportion of the population submitted to selection pressure and persistence of the drug.

Parasite of domestic animals and cultivated plants share the same characteristics concerning ecological factors, population size and intensity of the apparent selection pressure. Parasitic nematodes in plants or animals are characterised by an extremely high prevalence worldwide, with huge population size. An average hectare of soil in temperate area contains more than 10 billion pathogenic nematodes, and the majority of ruminants in grazing conditions are infected by parasitic nematodes. An average herd of 100 beef calves may harbour as much as five millions of strongyles nematodes. Available data on genetic diversity of nematode populations emphasise structured populations in plant and in animal parasitic nematodes, which is consistent with isolated populations in fields or in herds at the regional scale, with limited gene flow on large geographic scale in most cases (Hugall et al., 1994; Leignel \& Humbert, 2001) (see Blouin et al., 1992 for an exception) and hence limited diffusion of resistance genes. Nematode parasite of domestic animals and cultivated plants present adaptations to environmental conditions (climatic conditions, hosts specificity) which may alter response to selective pressure to antiparasitic drugs. Both groups may avoid the drug, either by dormancy of plant parasitic nematodes or by inhibition of fourth stage larvae in mucosa of animal host. Those specific states correspond to arrested development which may reduce efficiency of metabolised drugs. The eggs of cyst nematodes such as Globodera and Heterodera spp. are encased in the body of the female, forming a cyst. This state does not avoid exposure as nematicides pass through the cysts wall (Anonymous, 2001)

Management strategies aim at reducing nematode populations below damage thresholds because eradi- cation is neither possible nor ecologically conceivable in field situations. In ruminant farming, anthelmintics remain the most frequent control strategy. Although diverse, the most "classical" anthelmintic treatment frequency observed in small ruminants corresponds to two to three treatments a year (Kelly et al., 1981; Cabaret et al., 1986; Drudge et al., 1988). In plant parasitic nematodes, treatment protocols are also very diverse: from one application at planting for carbamates and organophosphates used in fruits and vegetables cultures (Jardine \& Todd, 1992), to repeated treatments during the season for Vydate ${ }^{\circledR}$, a carbamate used on the same cultures (Jardine \& Todd, 1992). For banana culture in tropical areas, it is recommended to apply treatments two to three times a year based on calendar dates, regardless of the chemical, to maintain nematode populations at low levels throughout the year (Sarah et al., 1996), which is similar to the situation described for nematode parasites of animals.

Selection by chemicals has existed for a long time: in control of animal-parasitic nematodes, first classes of drugs (organophophates and piperazines) were used since the 1950 's. Due to toxicity to the host, these families were less frequently used when anthelmintics with higher therapeutic index became available. Three main anthelmintic families appeared commercially in 1960's, 1970 's and 1980's, for benzimidazoles (BZ), imidazothiazoles/tetrahydropyrimidines (LEV) and macrocyclic lactones (AVM), respectively. In plant-parasitic nematode control, fumigants have been largely used since early 1940's, and first organophosphates (fenamiphos and ethoprop) and carbamates (carbofuran) were introduced commercially in 1960 's. A second wave of products appeared in early 1970's (aldicarb, cadusafos) reducing the use of the formers (carbofuran, fenamiphos).

Although chemicals are commonly used in the control of both plant and animal nematodes, it seems that drug resistance is a problem only for domestic animal breeding. What may be the role of nematode specific life traits or the role of environmental factors in the acquisition of drug resistance? These questions can be addressed by comparing the development of drug resistance in nematode parasites of domestic animals and cultivated plants.

In the first part of the paper, we examine the state of play of anthelmintic resistance in animal-parasitic nematodes. After a review of cases and arguments in favour of the development of nematicide resistance in plant-parasitic nematodes, we discuss the possible reasons why reported cases are so few and the consequences for anthelmintic resistance control in farm animal industry. 
STATE OF PLAY OF ANTHELMINTIC RESISTANCE IN NEMATODE PARASITES OF ANIMALS AND HUMAN

N ematode parasites infections affect all grazing ruminants world-wide. Available anthelmintics are discriminated on the basis of their mode of action. BZ bind selectively to beta-tubulin, LEV is agonist at nicotinic acetylcholine receptors, and AVM bind to receptors directing chloride channels (Martin, 1997). We can distinguish very distinct situations of the prevalence of anthelmintic resistance depending on host, parasite species and also drug families. In a general view, anthelmintic resistance is more frequent in goats, to a lesser extend in sheep and horses and it appears to be much less common in cattle (Cabaret, 2000) (Table I).

\section{Goat}

A recent survey indicated that anthelmintic resistance is present on almost all dairy goat farms in western France (Chartier et al., 1998). Anthelmintic resistance is mostly directed against $\mathrm{BZ}$, and secondarily against LEV and AVM (Cabaret, 2000). Anthelmintic resistant nematode genus are Trichostrongyles: mainly Haemonchus sp., Trichostrongylus sp. and Teladorsagia sp. and, in a lesser extent Oesophagostomum sp., Cooperia sp. and Nematodirus sp.

\section{Sheep}

In sheep farms, the same anthelmintic resistant species are found as in goat farms but the problem of resistance is mostly restricted to BZ and LEV families. Anthelmintic resistance is less frequent than in goats

\begin{tabular}{llccc}
\hline $\begin{array}{c}\text { Host } \\
\text { species }\end{array}$ & Parasite genus & BZ & $\begin{array}{c}\text { LEV- } \\
\text { MOR/PYR }\end{array}$ & AVM \\
\hline \multirow{2}{*}{ Goat } & Haemonchus & $\mathrm{R}$ & $\mathrm{S}$ & $\mathrm{R}$ \\
& Teladorsagia & $\mathrm{R}$ & $\mathrm{R}$ & $\mathrm{R}$ \\
& Trichostrongylus & $\mathrm{R}$ & $\mathrm{R}$ & $\mathrm{R}$ \\
\hline \multirow{2}{*}{ Sheep } & Haemonchus & $\mathrm{R}$ & $\mathrm{S}$ & $\mathrm{R}$ \\
& Teladorsagia & $\mathrm{R}$ & $\mathrm{R}$ & $\mathrm{R}$ \\
& Trichostrongylus & $\mathrm{R}$ & $\mathrm{R}$ & $\mathrm{R}$ \\
\hline Horse & Cyathostoma & $\mathrm{R}$ & $\mathrm{R}$ & $\mathrm{S}$ \\
\hline \multirow{2}{*}{ Cattle } & Cooperia & $\mathrm{R}$ & $\mathrm{S}$ & $\mathrm{R}$ \\
& Ostertagia & $\mathrm{S}$ & $\mathrm{R}$ & $\mathrm{S}$ \\
& Haemonchus & $\mathrm{S}$ & $\mathrm{R}$ & $\mathrm{S}$ \\
\hline \multirow{2}{*}{ Human } & Necator & $\mathrm{R}$ & $\mathrm{S}$ & $\mathrm{S}$ \\
& Ancylostoma & $\mathrm{S}$ & $\mathrm{R}$ & $\mathrm{S}$ \\
\hline
\end{tabular}

a Parasite are considered susceptible when no anthelmintic resistance record is available on the Commonwealth Agricultural Bureau (CAB) abstracts database.

Table I. - Anthelmintic resistance recorded in farm animals and human. farms: between 50 and $80 \%$ of sheep farms in western France showed BZ or LEV resistant nematodes (Chartier et al., 1998). Despite their limited use in the field, a few cases of organophosphates resistance have been recorded in nematode populations of sheep from Australia and USA (Trichostrongylidea, Kaufman et al., 1980; Green et al., 1981; Keys et al., 1993).

\section{Horses}

In horses, small strongyles (cyathostomes) have been found to be resistant to organophosphates in Poland (Betlejewska, 2000), to BZ all over the world (for review, Lyons et al., 1999) and resistance to pyrantel is becoming increasingly prevalent (for review, Kaplan, 2002). It is not known why AVM are still efficient although they have been used for more than 20 years. The main anthelmintic resistant genera are: Cyathostoma sp., Cylicostephanus sp. and Cylicocyclus sp. (Lyons et al., 1999).

Cattle

Until recently, cattle had been seen as the only grazing farm animal free of problems of anthelmintic resistance. However, in a recent review (Coles, 2002), Coles demonstrated that anthelmintic resistance in cattle is not as rare as thought: resistance in parasitic nematode is becoming a serious problem in intensive beef production in South America (Coles, 2002). The main parasitic genus are Ostertagia sp. and Cooperia sp. Anthelmintic resistance is directed against LEV (Dorny \& Vercruysse, 1994) and AVM families. Resistance to $\mathrm{BZ}$ is less frequent but a multispecific resistance to $\mathrm{BZ}$ was recorded recently (Mejia et al., 2003).

Human

Up today, there is no unequivocal evidence that resistance to anthelmintics in human nematode infections is an emerging problem. Recent reports mentioned failures of anthelmintic treatments of human hookworm infections (Geerts \& Gryseels, 2000): cases concern a BZ-resistant Necator americanus strain and a pyrantelresistant Ancylostoma duodenale strain. Taking into account the dramatic anthelmintic resistance situation observed in ruminant industry and the fact that main human parasite species are controlled only by one particular drug family (albendazole for hookworms and ivermectine for onchocerciasis), it is likely that resistant strains do exist and will develop sooner or latter, as a consequence of treatment selection (Geerts \& Gryseels, 2000). At first sight, the filariae Onchocerca volvulus appears as a good candidate to acquire anthelmintic resistance because disease control relies only on $\mathrm{AVM}$ and that onchocerciasis control programme consists in mass therapy. To the authors knowledge, there is no conclusive evidence for the emerging of AVM resistance in O. volvulus strains. Nevertheless, sensitivity of in vitro methods of drug resistance detec- 
tion is not well known: in contrast to veterinary parasitology, where methods and critical values that define anthelmintic resistance were established (Coles et al., 1992), there is no such guidelines in human parasitology. In contrast to strongyles, O. volvulus presents an indirect life cycle: anthelmintic resistant microfilariae must be transmitted to the insect vector and then return to the human to mate, multiply and maintain drug resistance gene in the parasite population. These critical points may explain the lack of anthelmintic resistance reports about human nematodes.

The Nematoda phylum consists of five clades (Blaxter, 1998) and resistance could be more easily acquired in one clade of the phylum. Animal-parasitic nematodes are present among four clades, with one group (Strongylida) being phylogenetically close to the free-living nematode $C$. elegans. Plant-parasitic nematodes represent three other independent groups (Fig. 1). Anthelmintic resistance appeared in several phylogenetic groups among the order of Strongylida. One may conclude that particular life traits found in this order may be responsible for facilitating the acquisition of drug resistance. Nevertheless, the order of Strongylida comprises nematode genus that parasite small ruminants as well as cattle, a host species for which very few cases of anthelmintic resistance exist. When farming management of small ruminant was applied to cattle farming, then anthelmintic resistance increased (Mejia et al., 2003). Anthelmintic resistance prevalence is largely dependant of factors such as the host species, the anthelmintic family and environmental factors such as farming management (Cabaret, 2000; Silvestre et al., 2002). Cases of AVM resistance recorded for $\mathrm{COO}-$ peria spp. in intensive beef production in New Zealand and the efficiency of this anthelmintic family against the same parasitic species in beef sucker herds from Europe (Coles, 2002) illustrates the importance of environmental factors in the acquisition of anthelmintic resistance.

The main contributing factors for the selection of anthelmintic resistance in parasites of domestic animals that have been identified in literature so far are:

i) the continuous use of a single drug family (drugs sharing the same mode of action) for years, even at as low frequency as one treatment a year selects for resistance (Albonico et al., 1999; Berrag et al., 2002); ii) an efficient selection pressure by anthelmintics that relies on the treatment of the whole parasite population (no refugia to escape selection pressure), gives a large contribution of resistant worms to the subsequent generation (Wyk, 2001);

iii) under-dosing of drugs: based on mathematical models and animal experimentation, the speed of anthelmintic resistance development is increased by under-dosing, in particular conditions, implying initial resistant gene frequency, intensity of under-dosing and the size of the parasite population under-dosed (Barnes et al., 1995; Silvestre et al., 2001);

iv) migration of infected hosts introduces an important flow of anthelmintic resistant gene in populations that are not submitted to selection pressure by treatments. This problem was evidenced for BZ resistance in

\begin{tabular}{|c|c|c|c|}
\hline & Order & Examples & Host \\
\hline & $\begin{array}{l}\text { Strongylida } \\
\text { Rhabditida }\end{array}$ & $\begin{array}{l}\text { Trichostongyles, small strongyles, hookworms } \\
\text { Caenorhabditis elegans }\end{array}$ & $\begin{array}{c}\text { animal } \\
\text { free-living }\end{array}$ \\
\hline & $\begin{array}{l}\text { Strongiloides } \\
\text { Tylenchida }\end{array}$ & Melö̈dogyne spp., Globodera spp. & $\begin{array}{l}\text { animal } \\
\text { plant }\end{array}$ \\
\hline & $\begin{array}{l}\text { Ascaridida } \\
\text { Spirurida }\end{array}$ & $\begin{array}{l}\text { Ascaris spp., Toxocaraspp. } \\
\text { Brugia spp., Onchocerca spp. }\end{array}$ & $\begin{array}{l}\text { animal } \\
\text { animal }\end{array}$ \\
\hline & Triplonchida & Paratrichodorus spp., Trichodorus spp. & plant \\
\hline & $\begin{array}{l}\text { Dorylaimida } \\
\text { Trichocephalida }\end{array}$ & $\begin{array}{l}\text { Xiphinemaspp. } \\
\text { Trichinella spp., Trichuris spp. }\end{array}$ & $\begin{array}{l}\text { plant } \\
\text { animal }\end{array}$ \\
\hline
\end{tabular}

Fig. 1. - Phylogenetic organisation of the phylum Nematoda, based on ribosomal subunit RNA genes (and other genes) adapted from (Blaxter, 1998). Among each clade (1 to 5 ) orders and species cited in the paper are mentioned. 
sheep and goat farms (Varady et al., 1993; Himonas \& Papadopoulos, 1994; Requejo-Fernandez et al., 1997). On the basis of this short review of the prevalence of anthelmintic resistance in animal-parasitic nematodes and the description of factors selecting for drug resistance, what may be the situation in plant-parasitic nematodes? What are the arguments in favour of the prevalence of nematicide resistance?

\section{STATE OF PLAY OF NEMATICIDE RESISTANCE IN FIELD CONDITIONS}

T Three arguments support the fact that nematicide resistance should be prevalent in field strains of plant-parasitic nematodes.

1. On the basis of their mode of action, organophosphates and carbamates are likely to induce nematicide resistance. Those compounds are highly persistent in comparison with anthelmintics: several months for phenamiphos, for instance (Paternelle \& Lhoutellier, 2001). It has been demonstrated that resistance is more prone to be selected with persistent compounds than with short-lived molecules (Dobson et al., 1996): nematodes that survive treatment have an enormous reproductive advantage during persistency period. These treatments should logically generate a highly efficient selection pressure on nematode populations.

2. For studies of xenobiotic resistance, a large collection of mutant strains of the free-living nematode, Caenorhabditis elegans, were obtained. Hodgkin et al. (1988) presented more than 20 genes that were identified in carbamates and organophosphates resistance (Table II). All ric mutants were recessive (Miller et al., 1996) and some other mutations also (unc-64 (Swin-

\begin{tabular}{lll}
\hline \multicolumn{1}{c}{ Drug family } & \multicolumn{1}{c}{$\begin{array}{c}\text { Generic } \\
\text { drug name }\end{array}$} & \multicolumn{1}{c}{ Gene } \\
\hline $\begin{array}{l}\text { Acetylcholine-esterase } \\
\text { inhibitor (organophosphates } \\
\text { and carbamates) }\end{array}$ & Aldicarb & $\begin{array}{l}\text { unc-10 } \\
\text { unc-64 } \\
\text { ric-8 } \\
\text { cha-1 } \\
\text { ric-3 } \\
\text { ric-4 } \\
\text { snb-1 }\end{array}$ \\
& & $\begin{array}{l}\text { unc-63 } \\
\text { cha-1 }\end{array}$ \\
\cline { 2 - 3 } & Trichlorphon & lev-1, 7, 8, 9, 10, 11, \\
& unc-22, 29, 38, 39, \\
& Levamisole 63, 74 \\
\hline $\begin{array}{l}\text { Nicotinic acetylcholine } \\
\text { receptor agonist } \\
\text { (imidazothiazoles) }\end{array}$ & & Ben-1 \\
\hline $\begin{array}{l}\text { Tubulin polymerisation } \\
\text { inhibitor (benzimidazoles) }\end{array}$ & Benomyl & \\
\hline
\end{tabular}

Table II. - Caenorhabditis elegans drug resistant mutants. deren et al., 1999)). But, it is worthy to note that some mutants exhibit partial embryonic or larval lethality (ric8, (Miller \& Rand, 2000), cha-1 (Rand \& Russell, 1984; Alfonso et al., 1994), unc-17, (Brenner, 1974; Alfonso et al., 1993), unc-104, (Otsuka et al., 1991; Nguyen et al., 1995) and in some strains, growth rate was significantly less than in wild type, even in the absence of the drug (unc-17, 18, 41, 75 and 104 for instance, in Nguyen et al., 1995). Even if this fitness cost may reduce the viability of homozygous mutants in field conditions, it is clear that plant-parasitic nematodes may use several genetic combinations to resist nematicide treatment (i.e. complementation of several mutated loci, or homozygosity of one major locus).

3. A lot of experimental studies demonstrated the adaptability of plant-parasitic nematodes to nematicide treatments. Main studies concerned organophosphates and carbamates. Rhabditis oxycerca populations exposed long-term to aldicarb and oxamyl (carbamates) developed a high resistance level to these compounds (Below et al., 1987). The biochemical mechanism of resistance relied on an increased activity of acetylcholine esterase, the target enzyme of carbamates. Non specific mechanisms of carbamates detoxification were also demonstrated (Below et al., 1987). This last point can explain the cross-resistance phenomenon observed for several nematicide compounds (Yamashita \& Viglierchio, 1987; Yamashita et al., 1988; Viglierchio \& Brown, 1989). Several experimental approaches were conducted to evaluate nematode adaptability to nematicide treatments. Results indicated that Criconemella xenoplax, Xiphinema index, Meloidogyne incognita and Pratylenchus vulmus displayed enhanced resistance against organophosphates and carbamates (carbofuran, phenamiphos, oxamyl and aldicarb) after a three-year-history of continuous monthly sub-lethal treatment. Selection resulted in a 10 to 70 -fold increase in nematicide resistance (Glazer et al., 1997). The heritability estimate $\mathrm{h}^{2}$ for phenamiphos and oxamyl resistance was high (between 0.31 and 0.71 ) in inbred lines of Heterorbabidis bacteriophora. The enhanced resistance was stable and continued after selection was relaxed (Glazer et al., 1997).

In contrast to these arguments, only one report is available about nematicide resistance sensu stricto in field strains of plant-parasitic nematodes (Table III). Carbofuran resistant strain of Pratylenchus scribneri was recorded in corn fields after four to five year-treatment with this nematicide (Smolik, 1978): carbofuran resistance was confirmed by laboratory studies of the P. scribneri strain.

Concurrently to this particular study, a large amount of literature mention a "lack of efficiency" of nematode infection control by nematicide in field conditions after 


\begin{tabular}{|c|c|c|c|}
\hline Drug family & & Generic drug name & $\begin{array}{c}\text { Resistant nematode } \\
\text { group }\end{array}$ \\
\hline $\begin{array}{l}\text { Acetylcholine-esterase inhibitor } \\
\text { (organophosphates and carbamates) }\end{array}$ & $\begin{array}{l}\text { Nematicide } \\
\text { Anthelmintic }\end{array}$ & $\begin{array}{l}\text { Carbofuran } \\
\text { Dichlorvos } \\
\text { Neguvon } \\
\text { Trichlorphon } \\
\text { Naphtalophos }\end{array}$ & $\begin{array}{l}\text { Paratylenchus } \\
\text { Cyathostominae } \\
\text { Trichostrongylidae } \\
\text { Trichostrongylidae } \\
\text { Haemonchus contortus }\end{array}$ \\
\hline $\begin{array}{l}\text { Nicotinic acetylcholine receptor agonist } \\
\text { (tetrahydropyrimidines and imidazothiazoles) }\end{array}$ & Anthelmintic & $\begin{array}{l}\text { Levamisole } \\
\text { Pyrantel-Morantel }\end{array}$ & $\begin{array}{l}\text { Cyathostominae, } \\
\text { Trichostrongylidae } \\
\text { Cyathostominae }\end{array}$ \\
\hline $\begin{array}{l}\text { Tubulin polymerisation inhibitor } \\
\text { (benzimidazoles) }^{\text {a. b }}\end{array}$ & Anthelmintic & All benzimidazoles & Trichostrongylidae \\
\hline Gamma-amino-butyric acid receptor agonist ${ }^{a}$ & Anthelmintic & Piperazine & Trichostrongylidae \\
\hline Phenols $^{c}$ & Nematicide & Xylenols & $\mathrm{NR}^{\mathrm{d}}$ \\
\hline Fumigant ${ }^{\mathrm{C}}$ & Nematicide & Methyl bromide & NR \\
\hline
\end{tabular}

a No nematicide product is available in this drug family.

${ }^{\mathrm{b}}$ Used as fungicide on fruits and vegetables after harvesting.

${ }^{c}$ No anthelmintic product is available in this drug family.

${ }^{\mathrm{d}}$ Not recorded.

Table III. - Reported cases of drug resistant species in plant and animal parasitic nematode.

a history of chemical control (for review, Karpouzas \& Walker, 1998) without the demonstration of nematicide resistance by in vitro experiments or strain characterisation. The microbial origin of the phenomenon of reduced efficiency was confirmed by the isolation of carbamates-degrading bacteria populations from soils after nematicide treatments (Rajagopal et al., 1986; Suett, 1986; Pussemier, 1990; Singh et al., 1990; Davis et al., 1994). Genes involved in carbamates degradation are encoded on plasmid and were cloned from several bacterial strains (Sphingomonas sp., Rhizobium sp., and Achromobacter sp.) (Dessaint et al., 2000; Ogram et al., 2000; Hashimoto et al., 2002).

As a conclusion, only one field nematicide resistance report can be confirmed for plant-parasitic nematode (Smolik, 1978), which is quite anecdotal in regards to the 1,330 reports on anthelmintic resistance of nematodes parasite of domestic animals recorded from 1973 to 2002, by the Commonwealth Agricultural Bureau (CAB) (Cabaret, 2000). It appears that nematicide resistance is not a major problem in plant production. Taking into account reasons presented above, this conclusion seems counter to intuition.

\section{DISCUSSION}

S tudies conducted on parasitic nematodes of small ruminants identified above all the role of an efficient selection pressure in the building up of resistance (Silvestre et al., 2002): it depends on the size of the population submitted to selection pressure and to their contribution to the next generation. The major reason for nematicide resistance being so rare has to do with the reduced selection pressure by nematicides.

1. Regulations are becoming more and more restrictive in regards to the usage of nematicide in agriculture. As a consequence, alternatives to chemical control are largely used in integrated control schemes (Fogain et al., 1996). Sanitation may prevent the spread of nematodes to uninfected fields: the usage of planting material certified free of nematode, the cleaning of machinery and equipment with water before moving between fields, and a proper irrigation and nutrition (addition of organic matter by manure or compost) reduce stress and may reduce nematode damage (Sharma \& Inderjit, 2001). Cultural practices are also effective methods. For instance, fields that are left fallow and kept weed-free, allow an important reduction of the nematode population (Smiley et al., 2000; Chabrier \& Queneherve, 2003). When feasible, planting in the autumn is preferable to the spring because plants can become established while soil temperatures are low, and nematode activity is minimal. When soil temperature rise in spring, plants are vigorous and can withstand the damages of nematode infections. Naturally nematode resistant plant varieties are quite abundant (Sarah et al., 1997) and some have been selected for bananas, beans, soybeans, cotton, tomato (Mollers et al., 1991). Plant-parasitic nematode resistance was easily selected in plant thanks to the identification of several nematode-resistance genes (Williamson, 1999), two of which have been cloned, Hs1pro-1 from sugarcane, giving resistance to Heterodera schachtii, 
and Mi from tomato, giving resistance to Meloidogyne incognita (Vos et al., 1998; Jung \& Wyss, 1999 ), transgenesis technology is also well established in plants and in vitro culture allows the efficient multiplication of the selected genotype. Conversely, in domestic animals, some evidence for a major gene conferring resistance to nematode infection was described once (Whitlock \& Madsen, 1958) but never confirmed then, reinforcing the hypothesis of a polygenic control. It is clear that progress obtained by selection for a major resistance gene is large compared with that for polygenically regulated traits with moderate heritability such as nematode resistance in ruminants (Albers et al., 1987). Crop rotation with non-host crops for two to three years seems to be another effective practice for species of plant-parasitic nematode that has a limited host range like cyst nematodes (Globodera spp. and Heterodera spp.) (Devine et al., 1999). Radopholus similis was efficiently controlled by rotation between banana and sweet potato or manioc (Sarah et al., 1993). The cultural method of "trap cropping" (Cadet, 1985) can be compared to the "diluting strategy" presented by Barger for ruminants (Barger, 1997). Two species of ruminants (cattle and sheep, for instance), that do not share the same spectrum of nematode parasites, graze the same pastures: decoy hosts (uptake of parasite without further development) contribute to reduce pasture contamination. This should be reflected in reduced nematode burden of ruminants at the end of the grazing season. For instance, Cadet (1985) proposed to exploit the specificity of Meloidogyne and Pratylenchus for sugarcane and peanuts, respectively. Preceding the cane with a crop of peanuts allows both nematodes control: peanuts act as a trap crop for Meloidogyne, while sugarcane eliminates Pratylenchus. Even if this method of control is not fully efficient, it may constitute an additional weapon in order to reduce selection pressure by nematicides. In many cases, nematode infections in a region are limited to one or two nematode species, and quarantine can be extremely efficient to manage nematodes control in the region (Hodda, 2003).

2. Comparing prevalence of resistance in relation to drug family (Table III) it appears that animal-parasitic nematodes acquired anthelmintic resistance essentially against BZ, LEV and in a lesser extent AVM, drugs that are not in use in agriculture. In plant-parasitic nematode control, nematicides are mainly fumigants and organophosphates/carbamates. The mode of action of nematicides may alter the selection pressure exerted on nematode populations. The effects of carbamates and organophosphates are readily reversible if nematicide exposure is reduced or eliminated (Opperman, 1992). Even if these compounds are persistent molecules, in the soil, run-off, leaching and biodegradation by microorganisms are well documented (Pussemier, 1990; Pus- semier, 1992; Davis et al., 1994; Dessaint et al., 2000) and may contribute to reduce exposure. These conditions may alter intensity of selection pressure by nematicides: susceptible nematodes can survive treatment and then, contribute efficiently to the subsequent generation. This point is particularly important because several genera of plant-parasitic nematodes exhibit modified reproductive strategies (i.e. mitotic or meiotic parthenogenesis in Meloidogyne spp.), facilitating the amplification of susceptible genotypes that escaped the selection pressure, maintaining susceptible genes in plant nematode populations (Jaffe et al., 1997).

However, intensity of selection pressure by nematicide treatments is not always low. In fact, banana production in Africa is well maintained by the use of non infected plant material, and the rotation with non-host crops for one year reduce $R$. similis population under detection levels (Sarah et al., 1996). However, in French West Indies, banana cultures are maintained only with nematicide treatments (carbamates or organophosphates) (Sarah et al., 1996). In some cases, one treatment a month is administered to control nematode populations (Mauléon, 2002, personal communication). Even with such an intense selection pressure, nematicides remain effective (Fogain et al., 1996).

Another explanation concerns genetic diversity of plant-parasitic nematodes: the mode of reproduction of several genera may reduce dramatically genetic diversity of populations (Blouin, 1998). Is this point sufficient to prevent the development of drug resistance? In ruminants, Trichostrongylid nematode populations are characterised by a large genetic diversity (Blouin et al., 1992; Grant, 1994), which probably favoured their adaptation to anthelmintics. Nevertheless, genetic diversity of Radopholus similis is much more important than in Meloidogyne spp. that is mitotic parthenogenetic (Elbadri et al., 2002) and, neither species has been recorded for the development of nematicide resistance in field populations.

\section{WHAT MAY BE THE POSSIBLE EXPLANATIONS FOR THE PAUCITY OF NEMATICIDE RESISTANCE DEVELOPMENT?}

1. There is no nematicide resistance in field populations, and infections are efficiently controlled by treatments. This situation is unlikely taking into account intensity of selection pressure presented above. Nevertheless, fertility of parasitic-plant nematode seems to be reduced compared to animal-parasitic nematodes, which may slow down the appearance of drug-resistance genes (Silvestre \& Humbert, 2002). For instance, the female Heterodera sp. lays between 200 and 400 eggs in cyst, and may complete three generations a year. This represents approximately 1,000 eggs/female/year. Trichostrongyles fertility may vary from several hundred to 
several thousands of eggs/female/day during weeks (Cabaret \& Ouhelli, 1984) and in general, these nematodes complete three generations a year.

2. There is nematicide resistance in field populations, and production level is maintained by others approaches than chemical control. The case of organic production of banana illustrates adequate levels of production in the absence of nematicide treatment. Growth yield of organically grown bananas is not significantly different from conventionally grown bananas (Nyanjage et al., 2000). Use of resistant varieties for leaf spot, wilt and nematodes, organic fertilisers and biological pesticides (Mustaffa \& Sathiamoorthy, 2001) in organic production is sufficient for controlling nematodes and other diseases.

It seems then that even if nematodes populations do acquire nematicide resistance in field conditions, it does not threaten production thanks to alternative methods of agricultural control.

\section{CONCLUSION}

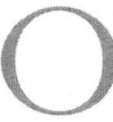

ur first aim was to compare drug resistance acquisition between nematodes that parasite plants and domestic animals to identify the role of particular nematodes life trait history or the importance of ecological factors in drug resistance acquisition. This short review of plant-parasitic nematode control shows that alternatives to chemotherapy are abundant and much more efficient than the control of animal-parasitic nematodes, reducing intensity of the selection pressure. Moreover, nematicide exposure of plant-parasitic nematode is reduced by biodegradation of nematicide by soil bacteria. Both phenomenon are responsible for a non efficient selection pressure, over the long term. Life traits of plant-parasitic nematodes such as fertility and reproductive strategy may also reduce the probability of resistant genes appearing and their transmission to the subsequent generation. Conversely, in animal farming, alternative control of parasitic nematodes are much less efficient. For instance, the concept of rotation tends to reduce infectivity of pastures, but for practical constraints, a farmer can not change his flock of sheep for a herd of cattle. This study illustrates the importance of an "efficient selection pressure" in the development of drug resistance. Selection exerted by anthelmintic treatment of farm animals is much more efficient than nematicide treatment in plant culture. This is the reason why anthelmintic resistance may be delayed but probably not avoided. This last point reinforces the importance of the early diagnosis of anthelmintic resistance in order to modify farming conditions to slow down resistance development.

\section{ACKNOWLEDGEMENTS}

A

first draft of this paper was presented at the $1^{\text {st }}$ meeting of the REBNH (Réseau pour l'Étude de la Biodiversité des Nématodes et des Helminthes, Muséum National d'Histoire Naturelle, Paris, France, 17-19 septembre 2001). We thank H. Mauléon (INRA, Guadeloupe), J.B. Bergé (INRA, Antibes) and R. Rivoal (INRA, Rennes), for information on nematode control in plants.

\section{REFERENCES}

Anonymous. Globodera and Heterodera spp. Bulletin OEPP, 2001, 31, 307-311.

Albers G.A.A., Gray G.D., Piper L.R., Barker J.S.F., Le Jambre L.F. \& BARGER I.A. The genetics of resistance and resilience to Haemonchus contortus infection in young merino sheep. International Journal for Parasitology, 1987, 17, 1355-1363.

Albonico M., Crompton D.W. \& Savioli L. Control strategies for human intestinal nematode infections. Advances in Parasitology, 1999, 42, 277-341.

Alfonso A., Grundahl K., Duerr J.S., Han H.P. \& Rand J.B. The Caenorhabditis elegans unc-17 gene: a putative vesicular acetylcholine transporter. Science, 1993, 261, 617-619.

Alfonso A., Grundahl K., McManus J.R. \& Rand J.B. Cloning and characterization of the choline acetyltransferase structural gene (cha-1) from C. elegans. Journal of Neuroscience, 1994, 14, 2290-2300.

BARGER I.A. Control by management. Veterinary Parasitology, 1997, 72, 493-506.

Barnes E.H., Dobson R.J. \& Barger I.A. Worm control and anthelmintic resistance: adventures with a model. Paras $i$ tology Today, 1995, 11, 56-63.

Below S., Kampfe L. \& Mueller A. Reaction of Rhabditis oxycerca after long-term exposure to aldicarb and oxamyl. II: enzyme changes in nematicide resistance. Nematologica, 1987, 33, 298-309.

Berrag B., Oukessou M. \& Cabaret J. Résistance des nématodes gastro-intestinaux des ovins et caprins aux benzimidazoles au Maroc. Animalis, 2002, 1, 25-28.

BetLejewska K.M. Strain of small strongyles (Cyathostominae) resistant to Banminth, Eqvalan, Panacur Paste and Rintal Plus in horses. Medycyna Weterynaryjna, 2000, 56, 395397.

Blaxter M. Caenorhabditis elegans is a nematode. Science, 1998, 282, 2041-2046.

BLouin M.S. Mitochondrial DNA diversity in nematodes. Journal of Helmintbology, 1998, 72, 285-289.

Blouin M.S., Dame J.B., Tarrant C.A. \& Courtney C.H. Unusual population genetics of a parasitic nematode: mtDNA variation within and among populations. Evolution, 1992, $46,470-476$.

BRENNER S. The genetics of Caenorhabditis elegans. Genetics, 1974, 77, 71-94. 
CABARET J. Anthelmintic resistance in goats: from fiction to facts. Proceeding of the $7^{\text {th }}$ international conference on goats. Tours-Poitiers, (France), 2000, 2, 793-794.

Cabaret J., Anjorand N., Leclerc C. \& Baril G. Goat farming in Touraine, France. II. Use of anthelmintics in adult goats. Recueil de Medecine Veterinaire, 1986, 162, 979-987.

Cabaret J. \& Ouhell H. Fertility of parasitic strongyles in the digestive system of sheep under natural conditions. Revue de Medecine Veterinaire, 1984, 135, 627-633.

CADET P. Research on cultural methods for the control of nematodes attacking sugar-cane in West Africa. Revue de Nématologie, 1985, 8, 377-382.

Chabrier C. \& Queneherve P. Control of the burrowing nematode (Radopholus similis Cobb) on banana: impact of the banana field destruction method on the efficiency of the following fallow. Crop Protection, 2003, 22, 121-127.

Chartier C., Pors I., Hubert J., Rocheteau D., Benott C. \& BerNARD N. Prevalence of anthelmintic resistant nematodes in sheep and goats in western France. Small Ruminant Research, 1998, 29, 33-41.

Coles G.C. Cattle nematodes resistant to anthelmintics: why so few cases? Veterinary Research, 2002, 33, 481-489.

Coles G.C. The future of veterinary parasitology. Veterinary Parasitology, 2001, 98, 31-39.

Coles G.C., Bauer C., Borgsteede F.H.M., Geerts S., Klei T.R., TAYlor M.A. \& Waller P.J. World Association for the Advancement of Veterinary Parasitology (WAAVP) methods for the detection of anthelmintic resistance in nematodes of veterinary importance. Veterinary Parasitology, 1992, 44, 35- 44 .

Davis R.F., Johnson A.W. \& Wauchope R.D. Accelerated degradation of fenamiphos and its metabolites in soil previously treated with fenamiphos. Journal of Nematology, 1994, 25, 679-685.

Dessaint S., Hartmann A., Parekh N.R. \& Fournier J.C. Genetic diversity of carbofuran-degrading soil bacteria. FEMS Microbiology Ecology, 2000, 34, 173-180.

Devine K.J., Dunne C., O'Gara F. \& Jones P.W. The influence of in-egg mortality and spontaneous hatching on the decline of Globodera rostochiensis during crop rotation in the absence of the host potato crop in the field. Nematology, 1999, 1, 637-645.

Dobson R.J., LeJambre L. \& Gill J.H. Management of anthelmintic resistance: inheritance of resistance and selection with persistent drugs. International Journal for Parasitology, 1996, 26, 993-1000.

DORNy P. \& Vercruysse J. Anthelmintic resistant nematodes in farm animals in Belgium, in: Anthelmintic resistance in nematodes of farm animals. Coles G.C., Borsteede F. \& Geert S (eds), Brussels, Belgium, 1994, 41-46.

Drudge J.H., Lyons E.T., Tolliver S.C., Lowry S.R. \& Fallon E.H. Piperazine resistance in population-B equine strongyles: a study of selection in Thoroughbreds in Kentucky from 1966 through 1983. American Joumal of Veterinary Research, 1988, 49, 986-994.

Elbadri G.A.A., Ley P.D., Waeyenberge L., Vierstraete A., Moens M. \& Vanfleteren J. Intraspecific variation in Radopholus similis isolates assessed with restriction fragment length polymorphism and DNA sequencing of the internal transcribed spacer region of the ribosomal RNA cistron. International Journal for Parasitology, 2002, 32, 199-205.

Fogain R., Archard R., Kwa M., Ferrier P. \& SARAh J.L. Nematode control on banana plantations in Cameroon: summary of 10 years of research on the efficacy of nematicide compounds. Fruits, 1996, 51, 151-161.

Geerts S. \& Gryseels B. Drug resistance in human helminths: current situation and lessons from livestock. Clinical Microbiology Reviews, 2000, 13, 207-222.

Glazer I., Salame L. \& Segal D. Genetic enhancement of nematicide resistance in entomopathogenic nematodes. Biocontrol Science \& Technology, 1997, 7, 499-512.

GRANT W.N. Genetic variation in parasitic nematodes and its implications. International Journal for Parasitology, 1994, 24, 821-830.

Green P.E., Forsyth B.A., Rowan K.J. \& Payne G. The isolation of a field strain of Haemonchus contortus in Queensland showing multiple anthelmintic resistance. Australian Veterinary Journal, 1981, 57, 79-84.

Hashimoto M., Fukui M., Hayano K. \& Hayatsu M. Nucleotide sequence and genetic structure of a novel carbaryl hydrolase gene (cehA) from Rhizobium sp. strain AC100. Applied and Environmental Microbiology, 2002, 68, 12201227.

Himonas C. \& Papadopoulos E. Anthelmintic resistance in imported sheep. Veterinary Record, 1994, 134, 456.

HoDDA M. Nematode management in the Australasian region. Australasian Nematology Newsletter, 2003, 14, 28-41.

Hodgkin J., Edgley M., Riddle D.L. \& Albertson D.G. Genetics, in: The nematode Caenorbabditis elegans. W.B. Wood and the community of $C$. elegans Researchers (eds), New York, 1988, 491-584.

Hugall A., Moritz C., Stanton J. \& Wolstenholme D.R. Low but strongly structured mitochondrial DNA diversity in root knot nematodes (Meloidogyne). Genetics, 1994, 136, 903912.

Jaffe K., Issa S., Daniels E. \& Haile D. Dynamics of the emergence of genetic resistance to biocides among asexual and sexual organisms. Journal of Theoretical Biology, 1997, 188, 289-299.

JARDINE D.J. \& TODD T.C. Nematode Management in Kansas: Chemical and Biological Control: Manhattan, Cooperative Extension Service, 1992, 12.

Jung C. \& Wyss U. New approaches to control plant parasitic nematodes. Applied Microbiology \& Biotechnology, 1999, 51, 439-446.

KAPLAN R.M. Anthelmintic resistance in nematodes of horses. Veterinary Research, 2002, 33, 491-507.

Karpouzas D.G. \& WaLKer A. Biodegradation of the nematicide ethoprophos in soils from the UK and Greece. Brighton Crop Protection Conference: Pests E Diseases, 1998, 1, 16-19.

Kaufman W.C., Sager F.C., Fields D. \& Kern S.C. Evaluation of anthelmintics in adult horses on a large breeding farm. Proceedings of the American Association of Equine Practitioners, 1980, 26, 45-46. 
Kelly J.D., Webster J.H., Griffin D.L., Whitlock H.V., Martin I.C.A. \& GUNAwAN M. Resistance to benzimidazole anthelmintics in equine strongyles. I. Frequency, geographical distribution and relationship between occurrence, animal husbandry procedures and anthelmintic usage. Australian Veterinary Journal, 1981, 57, 163-171.

LEIGNel V. \& Humbert J.F. Mitochondrial DNA variation in benzimidazole-resistant and -susceptible populations of the small ruminant parasite, Teladorsagia circumcincta. Journal of Heredity, 2001, 92, 503-506.

Keys R.G., ToOhEy L.A. \& Thilakan T.A. Survival by sheep body lice (Bovicola ovis) after plunge dipping in synthetic pyrethroid lousicides. Australian Veterinary Journal, 1993b, 70, 117.

Lyons E.T., Tolliver S.C. \& Drudge J.H. Historical perspective of cyathostomes: prevalence, treatment and control programs. Veterinary Parasitology, 1999, 85, 97-111.

MaRTIN R.J. Modes of action of anthelmintic drugs. Veterinary Journal, 1997, 154, 11-34.

Mejia M.E., Belisario M., Fernandez I.E.E.S. \& Cabaret J. Multispecies and multiple anthelmintic resistance on cattle nematodes in a farm in Argentina: the beginning of high resistance? The Veterinary Research, 2003, 34, 461-467.

Miller K.G., Alfonso A., Minh N., Crowell J.A., Johnson C.D. \& Rand J.B. A genetic selection for Caenorhabditis elegans synaptic transmission mutants. Proceedings of the National Academy of Sciences of the United States of America, 1996, 93, 12593-12598.

Miller K.G. \& RAND J.B. A role for RIC-8 (synembryn) and GOA-1 (Go alpha) in regulating a subset of centrosome movements during early embryogenesis in Caenorbabditis elegans. Genetics, 2000, 156, 1649-1660.

Mollers C., Hofferbert R., Schriener A. \& Wenzel G. Results from a field trial with tetraploid somatic potato hybrids. Bericht uber die Arbeitstagung, 1991, 129-135.

MustafFa M.M. \& Sathiamoorthy S. Organic farming in banana - problem and prospects. South Indian Horticulture, 2001, 49, 209-213.

Nguyen M., Alfonso A., Johnson C.D. \& Rand J.B. Caenorhabditis elegans mutants resistant to inhibitors of acetylcholinesterase. Genetics, 1995, 140, 527-696.

Nyanjage M.O., Wainwright H., Bishop C.F.H. \& Cullum F.J. Organic banana 2000: towards an organic banana initiative in the Caribbean. Report of the international workshop on the production and marketing of organic bananas by smallholder farmers, Santo Domingo, Dominican Republic, 31 October-4 November 1999. International Network. for the Improvement of Banana and Plantain, 2000, 174, 221-234.

Ogram A.V., Duan Y.P., Trabue S.L., Feng X., Castro H. \& Ou L.T. Carbofuran degradation mediated by three related plasmid systems. FEMS Microbiology Ecology, 2000, 32, 197-203.

Opperman C.H. The molecular basis of differential nematode sensitivity to nematicides. Nematology from molecule to ecosystem: Proceedings Second International Nematology Congress, 1992, 60-72.

Opperman C.H. \& BIRD D.M. The soybean cyst nematode, Heterodera glycines: a genetic model system for the study of plant-parasitic nematodes. Current Opinion in Plant Bio$\log y, 1998,1,342-346$.

Otsuka A.J., Jeyaprakash A., Garcia-Anoveros J., Tang L.Z., Fisk G., Hartshorne T., Franco R. \& Born T. The C. elegans unc-104 gene encodes a putative kinesin heavy chainlike protein. Neuron, 1991, 6, 113-122.

Paternelle M.C. \& Lhoutellier C. Index Phytosanitaire Acta 2001. Association de Coordination Technique Agricole, Paris, 2001.

Pussemier L. Accelerated degradation of carbofuran in a soil of sugarbeet cultivation. Mededelingen van de Faculteit Landbouwwetenschappen Rijksuniversiteit Gent, 1990, 55, 1301-1306

Pussemier L. A quick test for the assessment of an accelerated degradation of carbofuran and aldicarb in cultivated soils. Proceedings of the international symposium on environmental aspects of pesticide microbiology, 1992, 209-212.

Rajagopal B.S., Panda S. \& Sethunathan N. Accelerated degradation of carbaryl and carbofuran in a flooded soil pretreated with hydrolysis products, 1-naphthol and carbofuran phenol. Bulletin of Environmental Contamination \& Toxicology, 1986, 36, 827-832.

RAND J.B. \& Russell R.L. Choline acetyltransferase-deficient mutants of the nematode Caenorbabditis elegans. Genetics, 1984, 106, 227-248.

Raymond M., Callaghan A., Fort P. \& Pasteur N. Worldwide migration of amplified insecticide resistance genes in mosquitoes. Nature, 1991, 350, 151-153.

Requejo-Fernandez J.A., Martinez A., Meana A., Rojo-Vazquez F.A., Osoro K. \& Ortega-Mora L.M. Anthelmintic resistance in nematode parasites from goats in Spain. Veterinary Parasitology, 1997, 73, 83-88.

Roush R.T. \& McKenzie J.A. Ecological genetics of insecticide and acaricide resistance. Annual Review of Entomology, 1987, 32, 361-380.

SARAH J.L., Fogain R. \& VAlETte C. Nematode resistance in bananas: varietal screening and resistance mechanisms. Fruits, $1997,52,267-271$

Sarah J.L., Pinochet J. \& Stanton J. Radopholus similis Cobb, nématode parasite des bananiers. Parasites et ravageurs des Musa, fiche technique $n^{\circ} 1$ du Réseau international pour l'amélioration de la banane et de la banane plantain. 1996, 2 pages.

Sarah J.L., Price N. \& Fogain R. Banana nematodes. Fruits, 1993, 48, 32-33.

Sharma S.K. \& Inderjit S. Effect of soil amendment with cruciferous oil seed crops on Meloidogyne incognita. Plant Disease Research, 2001, 16, 277-279.

Silvestre A., Cabaret J. \& Humbert J.F. Effect of benzimidazole under-dosing on the resistant allele frequency in Teladorsagia circumcincta (Nematoda). Parasitology, 2001, 123, 103-111.

Silvestre A. \& Humbert J.F. Diversity of benzimidazole-resistance alleles in populations of small ruminant parasites. International Journal for Parasitology, 2002, 32, 921-928.

Silvestre A., Leignel V., Berrag B., Gasnier N., Humbert J.F., Chartier C. \& Cabaret J. Sheep and goat nematode resis- 
tance to anthelmintics: pro and cons among breeding management factors. Veterinary Research, 2002, 33, 465480 .

Singh N., Sahoo A. \& Sethunathan N. Accelerated degradation of carbofuran in standing water from carbofurantreated Azolla plots. Journal of Environmental Science $\varepsilon$ Health Part B: Pesticides, Food Contaminants, \& Agricultural Wastes, 1990, 25, 205-213.

Smiley R., Ball D., Wysocki D., Patterson L., Harris G., Walenta D., Rhinhart K. \& Merrifield K. Effects of crop rotation and tillage on root lesion nematode and wheat yield. Biological and Cultural Tests for Control of Plant Diseases, 2000, 15, 134-134.

SMoLIK J.D. Influence of previous insecticidal use on ability of carbofuran to control nematode populations in corn and effect on corn yield. Plant Disease Reporter, 1978, 62, 9599.

SuETT D.L. Accelerated degradation of carbofuran in previously treated field soils in the United Kingdom. Crop Protection, 1986, 5, 165-169.

Swinderen B.V., Saifee O., Shebester L., Roberson R., Nonet M.L. \& CROWDER C.M. A neomorphic syntaxin mutation blocks volatile-anesthetic action in Caenorhabditis elegans. Proceedings of the National Academy of Sciences of the United States of America, 1999, 96, 2479-2484.

Varady M., Praslicka J., Corba J. \& Vesely L. Multiple anthelmintic resistance of nematodes in imported goats. Veterinary Record, 1993, 132, 387-388.

Viglierchio D.R. \& Brown S.M. In vitro testing for nonfumigant-nematicide resistance in Heterodera schachtii. Revue de Nématologie, 1989, 12, 139-143.

Vos P., Simons G., Jesse T., Wijbrandi J., Heinen L., Hogers R., Frijters A., Groenendijk J., Diergaarde P., Reijans M., Fierens-Onstenk J., Both M.D., Peleman J., Llharska T., HonTELEZ J. \& ZabeaU M. The tomato Mi-1 gene confers resistance to both root-knot nematodes and potato aphids. Nature Biotechnology, 1998, 16, 1365-1369.

Whitlock J.H. \& Madsen H. The inheritance of resistance to trichostrongylidosis in sheep. II. Observations on the genetic mechanism in trichostrongylidosis. Cornell Veterinarian, 1958, 48, 134-145.

Williamson V.M. Plant nematode resistance genes. Current Opinion in Plant Biology, 1999, 2, 327-331.

Wood R.J. \& MANi G.S. The effective dominance of resistance genes in relation to the evolution of resistance. Pesticide Science, 1981, 12, 573-581.

WYK J.A.V. Refugia-overlooked as perhaps the most potent factor concerning the development of anthelmintic resistance. Onderstepoort Journal of Veterinary Research, 2001, 68, 55-67.

YAMASHITA T.T. \& ViglierChio D.R. Field resistance to nonfumigant nematicides in Xiphinema index and Meloidogyne incognita. Revue de Nematologie, 1987, 10, 327-332.

Yamashita T.T., Viglierchio D.R. \& Fan-Kuo F. Nonfumigant nematicide conditioned populations of Criconemella xenoplax and their responses to subsequent treatments. Revue de Nematologie, 1988, 11, 429-435.
Note: To Imit the number of references, recent reviews were cited when available but an expanded version of the literature consisting of original papers is available at:

http://www.tours.inra.fr/sfpar/liens.htm\#parasites

Reçu le 29 septembre 2003 Accepté le 16 décembre 2003 